\title{
Influence of Mast Cells in Drug-Induced Gingival Overgrowth
}

\author{
Tamilselvan Subramani, ${ }^{1}$ Vidhya Rathnavelu, ${ }^{2}$ \\ Swee Keong Yeap, ${ }^{3}$ and Noorjahan Banu Alitheen ${ }^{1}$ \\ ${ }^{1}$ Department of Cell and Molecular Biology, Faculty of Biotechnology and Biomolecular Sciences, \\ University Putra Malaysia, 43400 Serdang, Selangor, Malaysia \\ ${ }^{2}$ Department of Oral and Maxillofacial Pathology, Faculty of Dental Science, Sri Ramachandra University, \\ Porur, Chennai 600116, India \\ ${ }^{3}$ Institute of Bioscience, University Putra Malaysia, 43400 Serdang, Selangor, Malaysia \\ Correspondence should be addressed to Noorjahan Banu Alitheen; noorjahan@biotech.upm.edu.my
}

Received 2 October 2012; Revised 7 December 2012; Accepted 7 December 2012

Academic Editor: Giuseppe Valacchi

Copyright (C) 2013 Tamilselvan Subramani et al. This is an open access article distributed under the Creative Commons Attribution License, which permits unrestricted use, distribution, and reproduction in any medium, provided the original work is properly cited.

\begin{abstract}
Mast cells (MCs) are multifunctional effector cells that were originally thought to be involved in allergic disorders. Now it is known that they contain an array of mediators with a multitude of effects on many other cells. MCs have become a recent concern in drug-induced gingival overgrowth (DIGO), an unwanted outcome of systemic medication. Most of the studies have confirmed the significant presence of inflammation as a prerequisite for the overgrowth to occur. The inflammatory changes within the gingival tissue appear to influence the interaction between the inducing drug and the fibroblast activity. The development of antibodies to MC-specific enzymes, tryptase and chymase, has facilitated the study of mast cells in DIGO. Many immunohistochemical studies involving MCs have been conducted; as a result, DIGO tissues are found to have increased the number of MCs in the gingiva, especially in the area of fibrosis. At the cellular level, gingival fibrogenesis is initiated by several mediators which induce the recruitment of a large number of inflammatory cells, including MCs. The purpose of this paper is to access the roles played by MCs in gingival overgrowth to hypothesize a relationship between these highly specialized cells in the pathogenesis of DIGO.
\end{abstract}

\section{Introduction}

Drug-induced gingival overgrowth (DIGO) is previously termed as gingival hypertrophy or gingival hyperplasia by finding an increased number of fibroblasts in gingival connective tissues [1]. However, these earlier terms did not accurately reflect the histologic composition of enlarged gingiva. It is characterized by massive accumulation of extracellular matrix (ECM) components or decrease in the degradation of ECM of the gingival connective tissue and/or a combination of both of these mechanisms [2]. DIGO is an adverse effect with three types of drugs: phenytoin (Phe), an antiepileptic; cyclosporine-A (CsA), an immunosuppressant; and calcium channel blockers, such as nifedipine (Nif), which are widely prescribed for the treatment of various diseases [3-5]. Drug-induced gingival enlargement consists of soft tissue growth that begins at interdental papilla then develops to papilla and increases to marginal gingiva. As the tissue enlarges it develops a characteristically thickened and lobulated appearance (Figure 1). It may partially or completely cover the tooth surfaces, including the occlusal surfaces, as well as extending the other way, into the sulcus. The epithelial surface is usually smooth and fibrotic, but can be nodular in CsA-induced gingival enlargement [6]. If there is underlying periodontal disease then the tissues may be inflamed, red, or purplish in colour, and highly vascularised, with a tendency to bleed profusely [7]. Gingival enlargement tends to be more severe in areas where plaque accumulates, such as at the edges of fillings and around orthodontic appliances. Though clinically they may look like fibrosis, histopathological and biochemical studies have shown increased cells, collagen, and ECM and hence the term gingival overgrowth was coined $[4,5]$. Furthermore, the presence of various degrees of gingival inflammation is one reason for difficulty in the accurate assessment of DIGO, because inflammation acts as an exacerbation factor of gingival overgrowth. At the cellular 


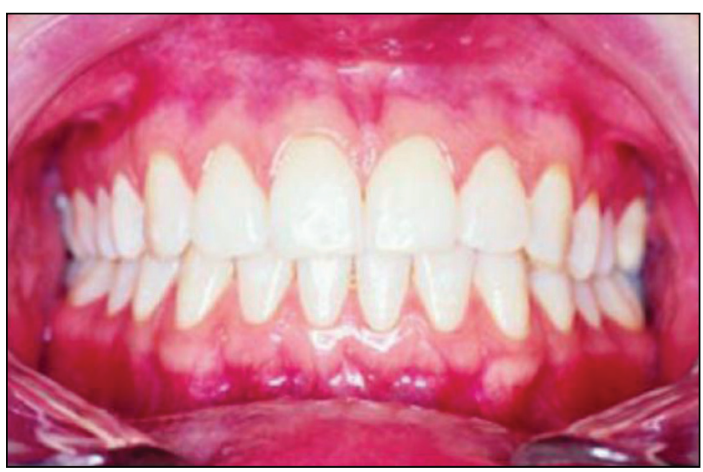

(a)

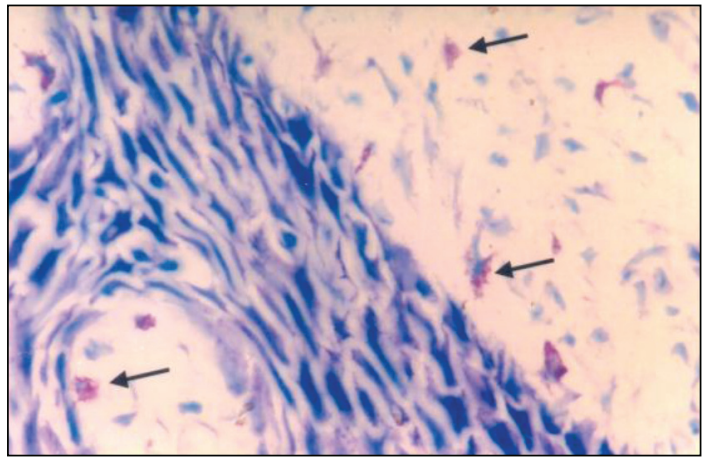

(c)

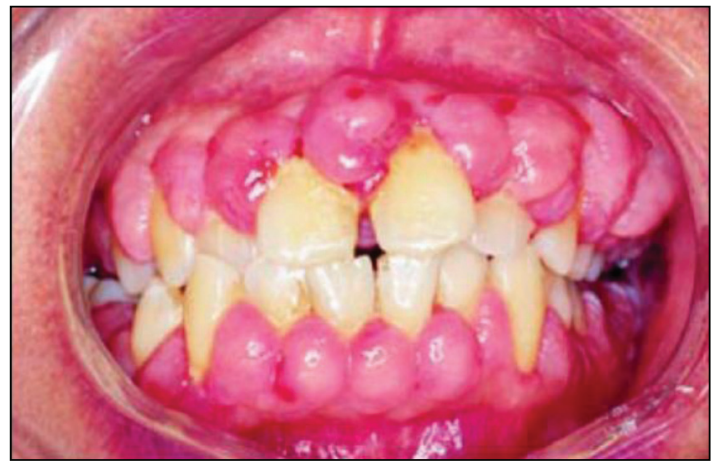

(b)

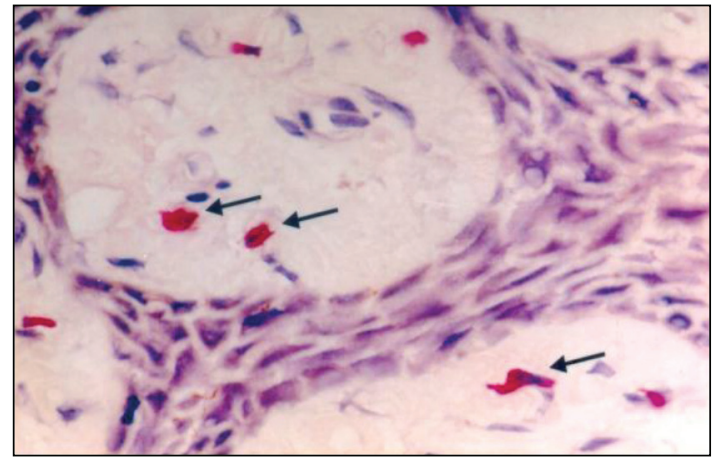

(d)

Figure 1

level, gingival fibrogenesis is initiated by several mediators which induce the recruitment of a large number of inflammatory cells, including mast cells (MCs) [8]. MCs are tissuespecific multifunctional cells, derived from hematopoietic progenitor in bone marrow. They do not develop into mature terminally differentiated mast cells until reaching the tissue or organ in which they become resident. They locate close to blood vessels, epithelia, and nerves in connective tissues, allowing their input in homeostatic functions and also being primary immune barriers $[9,10]$. Their anatomic distribution and structural relationships allow mast cells to modulate innate and adaptive immune responses; however, this role requires mast cell activation to stimulate cell degranulation together with release of mast cell mediators. In chronic inflammation, mast cells produce a range of bioactive amines, chemokines, cytokines, proteoglycans, and growth hormones, which mediate a diverse range of mast cell function [11]. Accordingly, this paper will describe the role of mast cells in gingival tissues as well as addressing what is currently known in regard to gingival mast cell and its influence on drug-induced gingival overgrowth.

\section{Gingival Mast Cells and Fibrosis}

Mast cells are found in all tissues of the oral cavity, including the gingival tissues $[12,13]$. It has been reported that mast cells were constantly present in healthy gingival tissue and located between epithelial cells and connective tissues [14,
15]. Proinflammatory cytokines that are released during the initial stage of the inflammation influence the migration of mast cells. In chronic periodontitis, there was an increase in the number of mast cells that may participate either in the destructive events or in the defense mechanisms of periodontal disease by secreting cytokines [16]. Following degranulation, mast cell mediators are deposited in large quantities in the extracellular environment, where they exert effects on endothelial cells and other cell types. The importance of mast cells in a number of pathological processes is beyond doubt, but because of their poorly defined physiological functions and phenotypic heterogeneity, they have always been a controversial issue [11]. It is now thought that mast cell-specific proteases (chymase and tryptase) represent the main criterion of differentiation: mast cells containing only tryptase $\left(\mathrm{MC}_{\mathrm{T}}\right)$ can be distinguished from those containing both tryptase and chymase $\left(\mathrm{MC}_{\mathrm{TC}}\right)$. Importantly, in several models both $\mathrm{MC}_{\mathrm{T}}$ and $\mathrm{MC}_{\mathrm{TC}}$ were present and directly involved in gingival fibrosis $[8,12]$. Chronic periodontitis and fibrosis involve a common sequence of events requiring the interaction of endothelial cells with infiltrating mast cell. Early events in this process, profibrotic stimuli, include key growth factors, transforming growth factor- $\beta$ (TGF- $\beta$ ) [13], and fibroblast growth factor [14] as well as inflammatory cytokines and chemokines facilitating mast cell recruitment and activation. The release of proteolytic enzymes like matrix metalloproteases (MMP) mediates fibrogenic injury and the overall balance of activators and inhibitors is altered in a manner favoring net matrix deposition. Mast cell effectively 
supports this process by elaborating the cytokines [15] and chemokines [16]. Mast cell produced mediators such as histamine, heparin, and TNF- $\alpha$ which can influence fibroblast proliferation, ECM synthesis, and degradation. TNF- $\alpha$ also upregulates $\mathrm{C}-\mathrm{C}$ chemokine receptor type 1 (CCR1) and regulated, on activation, normal $\mathrm{T}$ cell expressed and secreted (RANTES) expression which in turn triggers further mast cell degranulation [17]. Mast cell chymase is also known to stimulate MMP-9 which mediates basement membrane disruption [18]. On the whole, the cyclic activity of inflammatory mediator secretion and mast cell degranulation may result in the chronicity of gingival fibrosis (see Table 1 for details).

\section{Renin Angiotensin System and Mast Cell}

The gingiva provides all of the essential components for a functional renin angiotensin system (RAS), and there is an increasing evidence of the contribution of the local RAS in the pathogenesis of gingival overgrowth [19-21]. Angiotensin II (Ang II) is the effector peptide of RAS, which acts as a major role in regulation of collagen synthesis and growth modulating effects on fibroblasts [22-24]. In its target cells, Ang II binds to different subtypes of $G$ protein-coupled receptors and induces constriction [25], hypertrophy, and proliferation [26] via the angiotensin II type 1 (AT1) receptor. Angiotensin II type 2 (AT2) receptors mediate vasodilatation, growth inhibition [27], and apoptosis [28]. It has been known for some time that there are alternative pathways for converting Ang I to Ang II that do not require angiotensin converting enzyme (ACE). The accumulating evidence demonstrated the alternative Ang II-generating pathway through the enzyme mast cell chymase [29]. Mast cells synthesize renin and release during degranulation that can generate Ang II from Ang I [21, 30]. Nurmenniemi et al. 2004 have demonstrated the augmented mast cell and its enzyme chymase and tryptase in healthy human gingival connective tissue [8]. Despite the great number of studies on mast cell populations, at the present time studies regarding the stimulation of local RAS by mast cells in human gingiva are very few. Mariani et al., 1996, examined the overgrowth that affected gingiva of patients treated with cyclosporine after kidney transplant to evaluate the involvement of connective tissue [6]. The ultrastructural study showed that the dimensional increase was largely due to increased production of amorphous ground substance by fibroblasts, possibly resulting from an increased release of mast cells mediators. Furthermore, chymase inhibitors prevented Ang II and TGF- $\beta$ generation in a model of cardiac and kidney fibrosis $[31,32]$. In gingival fibrosis, chymase-positive mast cells infiltrate more in numbers in association with increased expression of stem cell factor and IL-8, known mast cell attractants. This was prevented by treatment with ACE inhibitors, suggesting a feedback link between Ang II-induced mast cell chemoattractants and ACE-independent generation of Ang II by mast cells [33]. Administration of a mast cell stabilizer reduces fibrosis and the number of chymase-positive mast cells, without affecting TGF- $\beta$ expression, consistent with a role for fibrosis-induced by chymase-generated AngII [34]. These studies collectively provide evidence for mast cell-induced gingival fibrosis by leading to mast cell activation of local RAS.

\section{Endothelin and Mast Cell}

Among the various mast cell mediators and their roles in gingival overgrowth, the function of endothelin-1 (ET-1) is particularly intriguing. Mast cells have been shown to directly produce this peptide [60]; thus, ET-1 may act in an autocrine mode in its release of mast cell mediators. Moreover, mast cells are likely to contribute indirectly to the formation of end thelin by releasing chymase, which can generate ET-1, by cleavage of big ET-1 [61]. ET-1 is a powerful vasoconstrictor with mitogenic activity on vascular smooth muscle and fibroblasts. There are currently two distinct human endothelin receptors known, ETA and ETB, which are members of the seven transmembrane $G$ protein-coupled rhodopsin superfamily $[62,63]$. Activation of both ETA and ETB on smooth muscle cells leads to vasoconstriction, whereas activation of ETB located on endothelial cells leads to vasodilation by increasing NO production [64]. Mounting evidence has strongly correlated elevated circulating and tissue levels of endothelin (ET)-1 in drug-induced gingival overgrowth in patients and animal models $[65,66]$. Mast cells store and release several products that are capable of activating MMPs. Although increased MMP activity has been observed in drug-induced gingival fibrosis, the recent findings implicate gingival mast cell degranulation as an in vivo mechanism responsible for activating MMPs and the subsequent ECM degradation $[39,40]$. Studies linking peritoneal and skin mast cells to tissue remodelling have shown that mast cell tryptase can activate interstitial collagenase (MMP-1) and stromelysin (MMP-3) under in vitro conditions [41, 42]. Studies using peritoneal mast cells isolated from mice have shown that chymase can activate MMP-2 and -9 [43]. Moreover, prevention of MMP-2 activation by treatment with the mast cell stabilizer nedocromil sodium firmly establishes that ET-1-induced MMP-2 activation is mediated via degranulation of resident mast cells [44]. In addition, growing evidence from other tissues suggests that ET-1 induces the expression of many types of MMPs as well as ECM protein expression, including collagens, laminin, and fibronectin (FN), in cell culture and animal models $[39,45]$. Further, RAS activation is probably the most important mechanistic link between mast cells and gingival fibrosis. In gingival overgrowth, locally formed ANG II will also stimulate ET-1 release and contribute to fibrosis. ET-1 was produced by cultured endothelial cells and MCs after Ang II stimulation [67, 68]. Furthermore, Ang II increases the production of ET-1 by human MCs and subsequently contributes to its mitogenic effects [69]. On the other hand, ET-1 enhanced the conversion of Ang I to Ang II in pulmonary artery endothelial cells [70]. Thus, the role of mast cells in the generation of fibrosis involves the direct effect of mast cell-derived endothelin-1 and angiotensin II, the exacerbation of preexisting inflammatory mediators, and the release of mast cell enzymes, such as renin and chymase. 
TABLE 1: Mast cell mediators and their roles in gingival tissue.

\begin{tabular}{|c|c|c|c|}
\hline Mediators & Model & Pathophysiological effect & References \\
\hline Histamine & $\begin{array}{l}\text { Human gingival fibroblast, } \\
\text { skin fibroblast }\end{array}$ & $\begin{array}{l}\text { Fibroblast proliferation and } \\
\text { collagen synthesis }\end{array}$ & {$[17,35,36]$} \\
\hline Serotonin & Rat gingival tissues & Vasoconstriction & {$[37]$} \\
\hline Arylsulphatases & Human gingival tissue & $\begin{array}{c}\text { Lipid and proteoglycan } \\
\text { hydrolysis }\end{array}$ & {$[38]$} \\
\hline MMP $1-3,9,10$ & Human gingival tissues & Matrix degradation & [39-45] \\
\hline Carboxypeptidase A & Human gingival tissues & Peptide processing & [38] \\
\hline Kininogenases & Rat gingival tissues & $\begin{array}{c}\text { Synthesis of vasodilatory } \\
\text { kinins }\end{array}$ & {$[46]$} \\
\hline Phospholipase & Human gingival fibroblast & $\begin{array}{l}\text { Fibroblast proliferation, } \\
\text { arachidonic acid generation }\end{array}$ & {$[47]$} \\
\hline Chymase & $\begin{array}{l}\text { Human gingival fibroblast, } \\
\text { human gingival tissues }\end{array}$ & $\begin{array}{l}\text { Fibroblast proliferation, } \\
\text { angiotensin II generation, }\end{array}$ & {$[8,12,29]$} \\
\hline Tryptase & $\begin{array}{l}\text { Human gingival fibroblast, } \\
\text { human gingival tissues }\end{array}$ & $\begin{array}{c}\text { fibroblast proliferation, } \\
\text { inflammation }\end{array}$ & {$[8,41,42,48,49]$} \\
\hline TGF- $\beta$ & $\begin{array}{l}\text { Human gingival fibroblast, } \\
\text { human gingival tissues }\end{array}$ & $\begin{array}{l}\text { Collagen synthesis, } \\
\text { fibronectin generation, } \\
\text { reduce MMP-1 synthesis }\end{array}$ & {$[13,31,32,34]$} \\
\hline b-FGF & $\begin{array}{c}\text { Human gingival fibrobalsts, } \\
\text { gingival tissues }\end{array}$ & Fibroblast proliferation & {$[50]$} \\
\hline CSF, GM-CSF & $\begin{array}{l}\text { Human gingival fibroblast, } \\
\text { human gingival tissues }\end{array}$ & $\begin{array}{c}\text { Fibroblast proliferation, } \\
\text { collagen synthesis, cytokine } \\
\text { generation }\end{array}$ & {$[13,50,51]$} \\
\hline $\begin{array}{l}\text { Chondroitin sulfate, } \\
\text { Heparin, } \\
\text { Hyaluronic acid }\end{array}$ & $\begin{array}{l}\text { Human gingival fibroblast } \\
\text { Human gingival tissues }\end{array}$ & $\begin{array}{l}\text { Inflammation, regulation of } \\
\text { cell addition and trafficking }\end{array}$ & {$[29,38,52]$} \\
\hline Chemotactic factors & Human gingival tissues & Leukocytes infliltration & {$[51]$} \\
\hline $\begin{array}{l}\text { Corticotropin releasing } \\
\text { factor, } \\
\text { Endorphins, } \\
\text { Somatostatin }\end{array}$ & $\begin{array}{c}\text { Human gingival tissues and } \\
\text { crevicular fluid, } \\
\text { Rat oral tissues }\end{array}$ & $\begin{array}{c}\text { Vasodilatation, analgesia, } \\
\text { inflammation }\end{array}$ & {$[38,53,54]$} \\
\hline Bradykinin & $\begin{array}{c}\text { Human gingival tissues, } \\
\text { mouse oral tissues }\end{array}$ & Antiinflammatory & {$[54]$} \\
\hline Substance P & Human gingival fibroblast & Inflammation & {$[54]$} \\
\hline $\begin{array}{l}\text { Vasoactive intestinal } \\
\text { peptide }\end{array}$ & $\begin{array}{l}\text { Human gingival tissues } \\
\text { Rat mandibular gingiva }\end{array}$ & Vasodilatation & {$[54]$} \\
\hline Leukotriene & $\begin{array}{l}\text { Human gingival tissues, } \\
\text { human gingival fibroblast, } \\
\text { rat oral tissues }\end{array}$ & Leukocyte chemotaxis & {$[1,54-56]$} \\
\hline Platelet activating factor & $\begin{array}{l}\text { Human gingival tissues, rat } \\
\text { tibiae, gingival fibroblasts. }\end{array}$ & $\begin{array}{l}\text { Vasodilatation } \\
\text { Vasoconstriction }\end{array}$ & {$[3,53,54,56]$} \\
\hline Prostaglandin & $\begin{array}{c}\text { Human gingival tissues, } \\
\text { gingival fibroblast, }\end{array}$ & $\begin{array}{l}\text { Inflammation, fibroblast } \\
\text { proliferation }\end{array}$ & {$[1,5,54,55]$} \\
\hline Nitric Oxide & $\begin{array}{l}\text { Crevicular fluid from } \\
\text { DIGO developed patients, } \\
\text { human gingival tissues }\end{array}$ & $\begin{array}{l}\text { Vasodilatation, } \\
\text { neurotransmission }\end{array}$ & {$[4,5,57]$} \\
\hline $\begin{array}{l}\text { IL- } 1,2,3,4,5,6,8,9,10 \text {, } \\
13,16 .\end{array}$ & $\begin{array}{l}\text { Human gingival tissues, } \\
\text { gingival fibroblast }\end{array}$ & $\begin{array}{l}\text { Inflammation, leukocyte } \\
\text { migration, fibroblast } \\
\text { proliferation }\end{array}$ & {$[13,38,50,54]$} \\
\hline INF- $\gamma$, MIF & Human gingival tissues & $\begin{array}{c}\text { Inflammation, leukocyte } \\
\text { proliferation, and } \\
\text { activation. }\end{array}$ & {$[54]$} \\
\hline
\end{tabular}


TABLe 1: Continued.

\begin{tabular}{|c|c|c|c|}
\hline Mediators & Model & Pathophysiological effect & References \\
\hline TNF- $\alpha$ & $\begin{array}{l}\text { Human gingival tissues, } \\
\text { gingival crevicular fluid }\end{array}$ & $\begin{array}{l}\text { Gingival inflammation, } \\
\text { collagen synthesis, } \\
\text { fibroblast proliferation }\end{array}$ & {$[29,38,50,58,59]$} \\
\hline RANTES & Human gingival tissues & $\begin{array}{l}\text { Chemoattractant, collagen } \\
\text { synthesis, fibroblast } \\
\text { proliferation, TNF- } \alpha \\
\text { generation }\end{array}$ & {$[17,54,55]$} \\
\hline MCP-1, 3, 4 . & Human gingival tissues & $\begin{array}{c}\text { Chemoattractant, gingival } \\
\text { inflammation }\end{array}$ & {$[54]$} \\
\hline
\end{tabular}

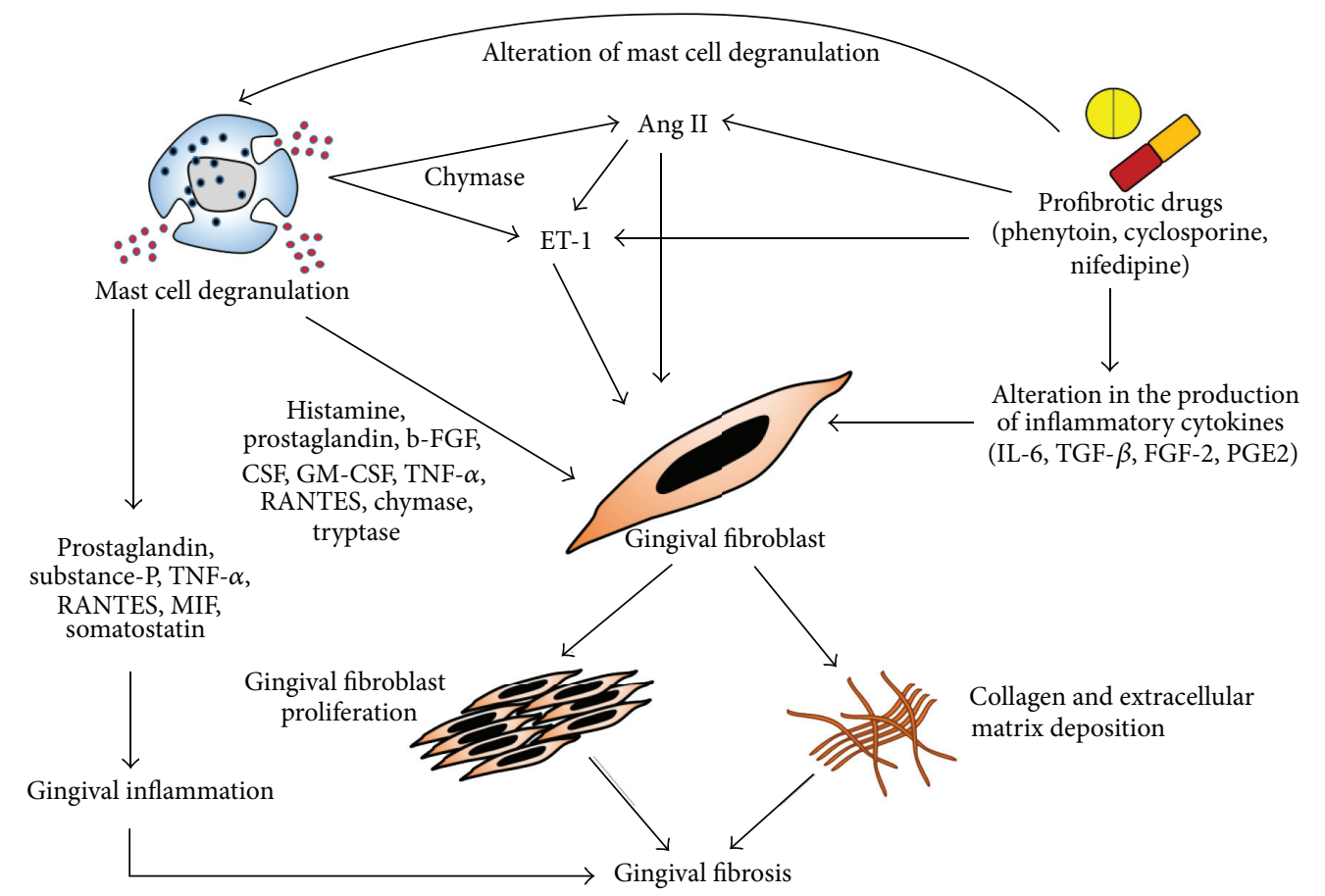

Figure 2

\section{Experimental Evidence Exploring the Role of Mast Cells in Gingival Overgrowth}

A number of studies have found that mast cells are involved in gingival overgrowth thus showing that they play a broader role than originally thought. It involves a multistage inflammatory process with fibroblast activation, inflammatory cell infiltration, and ECM expansion that is orchestrated by a network of cytokines/chemokines, growth factors, adhesion molecules, and signaling processes (Figure 2). In vitro studies have pointed out the potential for mast cells to induce fibroblast proliferation and collagen synthesis. Takeda and colleagues reported the marked elevations in total amount of mast cell granules in gingival fibroblast. This finding was interpreted as phagocytosis of mast cell granules by fibroblasts and suggested that mast cells play some role in fibroblast activity in human connective tissue [71]. The immunohistochemical expression of mast cell tryptase in inflammatory fibrous gingival hyperplasia demonstrated the involvement of mast cells in the induction of fibrosis by observing increased mast cell degranulation in fibrous tissues [48]. MC tryptase, by virtue of its capacity to activate fibroblast-expressed protease-activated receptors eventually in conjunction with heparin, could be an important mediator in this effect. MC chymase could also play a role. Indeed, chymase-positive gingival overgrowth patients showed significantly increased fibrotic lesions in the gingival tissues compared with chymase-negative patients [49]. A recently published study demonstrated that mast cell tryptase and chymase were expressed significantly higher in DIGO tissues compared to healthy gingiva and may contribute to alterations in basement membranes [8]. In one clinical study on CsA induced gingival overgrowth found the dimensional increase of amorphous ground substances by fibroblasts and this was possibly resulting from an increased release of mast cell mediators [6]. In contrast to this, Asahara et al., 
2000, demonstrated that mast cells are not necessary in the development of cyclosporin A-induced gingival hyperplasia, and that the increased number of mast cell observed in the enlarged gingiva may be a secondary effect of gingival hyperplasia [72]. On the other hand, it has been shown that mast cells were found to be increased in nifedipine as well as phenytoin-induced gingival overgrowth and mast cell chymase facilitating the augmented expression of TGF- $\beta$ [31]. The chymase also increases cell proliferation and type I collagen synthesis in fibroblasts and chymase inhibitors completely suppress this increased proliferation $[73,74]$. One study demonstrated the significant stimulation of 5 alphareductase activity in human gingival fibroblasts by mastcell histamine, alone and in combination with phenytoin [35]. The findings suggested a novel hypothesis that mastcell-mediated androgen action in the gingiva in response to phenytoin could contribute to gingival overgrowth. On the other hand, an ultrastructural study of the CsA-induced gingival overgrowth tissues showed the increased production of amorphous ground substance by fibroblasts, possibly resulting from an increased release of histamine by mast cells [36]. Mast cells have been associated with fibrosis in other organs besides gingival tissues, including kidney, heart, lung, and liver. Models of gingival fibrosis in mast cell-deficient mice have not been extensively studied. The available in vitro data $[6,8,37]$ showed the functional role of mast cells in fibrogenesis and suggested the net outcome of mast cell involvement as a profibrotic stimulator.

\section{Conclusion}

In summary, mast cells participate in many inflammatory oral diseases, particularly those associated with fibrosis. They possess very diverse roles ranging from proinflammatory to immunomodulatory. Upon their activation, they promote the local RAS generation consequently able to stimulate endothelin and other profibrotic mediators. What can be observed from the studies being done in this field is that there are some consistent findings as well as some fragmented findings. Taken together, these findings clearly demonstrate the central role of mast cells in DIGO; however, future research will contribute significantly to the understanding of the influence of mast cells in DIGO.

\section{References}

[1] A. Dongari, H. T. McDonnell, and R. P. Langlais, "Druginduced gingival overgrowth," Oral Surgery Oral Medicine and Oral Pathology, vol. 76, no. 4, pp. 543-548, 1993.

[2] J. M. Thomason, R. A. Seymour, and N. Rice, "The prevalence and severity of cyclosporin and nifedipine-induced gingival overgrowth," Journal of Clinical Periodontology, vol. 20, no. 1, pp. 37-40, 1993.

[3] M. Sano, N. Ohuchi, T. Inoue et al., "Proliferative response to phenytoin and nifedipine in gingival fibroblasts cultured from humans with gingival fibromatosis," Fundamental and Clinical Pharmacology, vol. 18, no. 4, pp. 465-470, 2004.
[4] R. A. Seymour, J. M. Thomason, and J. S. Ellis, "The pathogenesis of drug-induced gingival overgrowth," Journal of Clinical Periodontology, vol. 23, no. 3, pp. 165-175, 1996.

[5] R. A. Seymour, J. S. Ellis, and J. M. Thomason, "Risk factors for drug-induced gingival overgrowth," Journal of Clinical Periodontology, vol. 27, no. 4, pp. 217-223, 2000.

[6] G. Mariani, C. Calastrini, F. Carinci, L. Bergamini, F. Calastrini, and G. Stabellini, "Ultrastructural and histochemical features of the ground substance in cyclosporin A-induced gingival overgrowth," Journal of Periodontology, vol. 67, no. 1, pp. 21-27, 1996.

[7] R. I. Marshall and P. M. Bartold, "A clinical review of druginduced gingival overgrowths," Australian Dental Journal, vol. 44, no. 4, pp. 219-232, 1999.

[8] P. K. Nurmenniemi, H. E. Pernu, and M. L. E. Knuuttila, "Mast cell subpopulations in gingival overgrowth induced by immunosuppressive and nifedipine medication," Journal of Periodontology, vol. 75, no. 7, pp. 933-938, 2004.

[9] A. C. Batista, C. O. Rodini, and V. S. Lara, "Quantification of mast cells in different stages of human periodontal disease," Oral Diseases, vol. 11, no. 4, pp. 249-254, 2005.

[10] R. A. J. Eady, T. Cowen, and T. F. Marshall, "Mast cell population density, blood vessel density and histamine content in normal human skin," British Journal of Dermatology, vol. 100, no. 6, pp. 623-633, 1979.

[11] M. Welle, "Development, significance, and heterogeneity of mast cells with particular regard to the mast cell-specific proteases chymase and tryptase," Journal of Leukocyte Biology, vol. 61, no. 3, pp. 233-245, 1997.

[12] D. D. Metcalfe, D. Baram, and Y. A. Mekori, "Mast cells," Physiological Reviews, vol. 77, no. 4, pp. 1033-1079, 1997.

[13] K. Norrby, "Mast cells and de novo angiogenesis: angiogenic capability of individual mast-cell mediators such as histamine, TNF, IL-8 and bFGF," Inflammation Research, vol. 46, no. 1, pp. S7-S8, 1997.

[14] E. Rubinchik and F. Levi-Schaffer, "Mast cells and fibroblasts: two interacting cells," International Journal of Clinical and Laboratory Research, vol. 24, no. 3, pp. 139-142, 1994.

[15] R. M. Marks, W. R. Roche, and M. Czerniecki, "Mast cell granules cause proliferation of human microvascular endothelial cells," Laboratory Investigation, vol. 55, no. 3, pp. 289-294, 1986.

[16] G. Marone, C. Stellato, P. Mastronardi, and B. Mazzarella, "Mechanisms of activation of human mast cells and basophils by general anesthetic drugs," Annales Françaises D’Anesthésie Et De Réanimation, vol. 12, no. 2, pp. 116-125, 1993.

[17] Z. Z. Zhao, P. B. Sugerman, X. J. Zhou, L. J. Walsh, and N. W. Savage, "Oral and maxillofacial pathology: mast cell degranulation and the role of T cell RANTES in oral lichen planus," Oral Diseases, vol. 7, no. 4, pp. 246-251, 2001.

[18] N. Di Girolamo and D. Wakefield, "In vitro and in vivo expression of interstitial collagenase/MMP-1 by human mast cells," Developmental Immunology, vol. 7, no. 2-4, pp. 131-142, 2000.

[19] N. Basso and N. A. Terragno, "History about the discovery of the renin-angiotensin system," Hypertension, vol. 38, no. 6, pp. 1246-1249, 2001.

[20] P. P. De Andrade Santos, C. F. W. Nonaka, L. P. Pinto, and L. B. De Souza, "Immunohistochemical expression of mast cell tryptase in giant cell fibroma and inflammatory fibrous hyperplasia of the oral mucosa," Archives of Oral Biology, vol. 56, no. 3, pp. 231-237, 2011. 
[21] R. B. Silver, A. C. Reid, C. J. Mackins et al., "Mast cells: a unique source of renin," Proceedings of the National Academy of Sciences of the United States of America, vol. 101, no. 37, pp. 13607-13612, 2004.

[22] M. J. Peach, "Renin angiotensin system: biochemistry and mechanisms of action," Physiological Reviews, vol. 57, no. 2, pp. 313-370, 1977.

[23] V. J. Dzau, "Cell biology and genetics of angiotensin in cardiovascular disease," Journal of Hypertension, Supplement, vol. 12, no. 4, pp. S3-S10, 1994.

[24] M. R. W. Ehlers and J. F. Riordan, "Angiotensin-converting enzyme: new concepts concerning its biological role," Biochemistry, vol. 28, no. 13, pp. 5311-5318, 1989.

[25] J. E. Fildes, A. H. Walker, B. Keevil, I. V. Hutchinson, C. T. Leonard, and N. Yonan, "The effects of ACE inhibition on serum angiotensin II concentration following cardiac transplantation," Transplantation Proceedings, vol. 37, no. 10, pp. 4525-4527, 2005.

[26] M. Horiuchi, M. Akishita, and V. J. Dzau, "Molecular and cellular mechanism of angiotensin II-mediated apoptosis," Endocrine Research, vol. 24, no. 3-4, pp. 307-314, 1998.

[27] H. Matsubara, "Pathophysiological role of angiotensin II type 2 receptor in cardiovascular and renal diseases," Circulation Research, vol. 83, no. 12, pp. 1182-1191, 1998.

[28] J. O. Kokkonen, J. Saarinen, and P. T. Kovanen, "Regulation of local angiotensin II formation in the human heart in the presence of interstitial fluid: inhibition of chymase by protease inhibitors of interstitial fluid and of angiotensin-converting enzyme by ANG-(1-9) formed by heart carboxypeptidase Alike activity," Circulation, vol. 95, no. 6, pp. 1455-1463, 1997.

[29] C. Becari, E. B. Oliveira, and M. C. Salgado, "Alternative pathways for angiotensin II generation in the cardiovascular system," Brazilian Journal of Medical and Biological Research, vol. 44, no. 9, pp. 914-919, 2011.

[30] J. Katada, M. Muramatsu, M. Hayashi, and M. Hattori, "Role of mast cell chymase in angiotensin-induced vascular contraction of hamster cheek pouch microvessels," European Journal of Pharmacology, vol. 379, no. 1, pp. 63-72, 1999.

[31] J. D. Swales and N. J. Samani, "Localisation and physiological effects of tissue renin-angiotensin systems," Journal of Human Hypertension, vol. 3, no. 1, pp. 71-77, 1989.

[32] R. A. Skidgel, W. W. Schulz, L. T. Tam, and E. G. Erdos, "Human renal angiotensin I converting enzymeand neutral endopeptidase," Kidney International, vol. 31, no. 20, pp. S45-S48, 1987.

[33] S. E. Jones, D. J. Kelly, A. J. Cox, Y. Zhang, R. M. Gow, and R. E. Gilbert, "Mast cell infiltration and chemokine expression in progressive renal disease," Kidney International, vol. 64, no. 3, pp. 906-913, 2003.

[34] N. Ohuchi, Y. Taniguchi, K. Hayashi et al., "Contribution of TGF-ALPHA to EGF receptor transactivation leading to proliferative response of rabbit gingival fibroblasts to angiotensin II and endothelin-1," Journal of Pharmacological Science, vol. 100, supplement 1, no. 1, p. 271P, 2006.

[35] M. Soory and A. Suchak, "The effects of human mast-cell products and of phenytoin on androgen $5 \alpha$-reductase expression in human gingival fibroblasts," Archives of Oral Biology, vol. 46, no. 9, pp. 847-855, 2001.

[36] N. Buduneli, O. Sa冈ol, G. Atilla, S. Duman, and P. Holmstrup, "Immunohistochemical analysis of epidermal growth factor receptor in cyclosporin A-induced gingival overgrowth," Acta Odontologica Scandinavica, vol. 59, no. 6, pp. 367-371, 2001.
[37] N. P. Kerezoudis, G. G. Nomikos, L. M. Olgart, and T. H. Svensson, "Serotonin in rat oral tissues: role of 5-HT1 receptors in sympathetic vascular control," European Journal of Pharmacology, vol. 275, no. 2, pp. 191-198, 1995.

[38] B. L. Pihlstrom, B. S. Michalowicz, and N. W. Johnson, "Periodontal diseases," Lancet, vol. 366, no. 9499, pp. 1809-1820, 2005.

[39] D. Gómez-Garre, M. Ruiz-Ortega, M. Ortego et al., "Effects and interactions of endothelin-1 and angiotensin II on matrix protein expression and synthesis and mesangial cell growth," Hypertension, vol. 27, no. 4, pp. 885-892, 1996.

[40] T. Tsuruda, L. C. Costello-Boerrigter, and J. C. Burnett, "Matrix metalloproteinases: pathways of induction by bioactive molecules," Heart Failure Reviews, vol. 9, no. 1, pp. 53-61, 2004.

[41] M. Lees, D. J. Taylor, and D. E. Woolley, "Mast cell proteinases activate precursor forms of collagenase and stromelysin, but not of gelatinases A and B," European Journal of Biochemistry, vol. 223, no. 1, pp. 171-177, 1994.

[42] K. Suzuki, M. Lees, G. F. J. Newlands, H. Nagase, and D. E. Woolley, "Activation of precursors for matrix metalloproteinases 1 (interstitial collagenase) and 3 (stronnelysin) by rat mast-cell proteinases I and II," The Biochemical Journal, vol. 305, no. 1, pp. 301-306, 1995.

[43] E. Tchougounova, A. Lundequist, I. Fajardo, J. O. Winberg, M. Åbrink, and G. Pejler, "A key role for mast cell chymase in the activation of pro-matrix metalloprotease- 9 and pro-matrix metalloprotease-2," Journal of Biological Chemistry, vol. 280, no. 10, pp. 9291-9296, 2005.

[44] A. R. Pradeep, C. N. Guruprasad, P. Swati, and C. Shikha, "Crevicular fluid endothelin-1 levels in periodontal health and disease," Journal of Periodontal Research, vol. 43, no. 3, pp. 275-278, 2008.

[45] D. Fraccarollo, P. Galuppo, J. Bauersachs, and G. Ertl, "Collagen accumulation after myocardial infarction: effects of ETA receptor blockade and implications for early remodeling," Cardiovascular Research, vol. 54, no. 3, pp. 559-567, 2002.

[46] H. A. Gordon, S. Rovin, and G. Bruckner, "Blood flow, collagen components of oral tissue and salivary kallikrein in young to senescent, germfree and conventional rats: a study on the etiologic factors of periodontal disease," Gerontology, vol. 24, no. 1, pp. 1-11, 1978.

[47] T. Hattori, T. Ara, and P. Wang, "Participation of tyrosine kinase and phospholipase $\mathrm{C} \gamma$ in isradipine-induced proliferation of cultured human gingival fibroblasts," European Journal of Medical Research, vol. 10, no. 12, pp. 543-546, 2005.

[48] M. Artuc, U. Muscha Steckelings, and B. M. Henz, "Mast cell-fibroblast interactions: human mast cells as source and inducers of fibroblast and epithelial growth factors," Journal of Investigative Dermatology, vol. 118, no. 3, pp. 391-395, 2002.

[49] S. S. Craig and L. B. Schwartz, "Tryptase and chymase, markers of distinct types of human mast cells," Immunologic Research, vol. 8, no. 2, pp. 130-148, 1989.

[50] T. Sasaki and E. Maita, "Increased bFGF level in the serum of patients with phenytoin-induced gingival overgrowth," Journal of Clinical Periodontology, vol. 25, no. 1, pp. 42-47, 1998.

[51] M. I Uzel, A. Kantarci, H. H. Hong et al., "Connective tissue growth factor in drug-induced gingival overgrowth," Journal of Periodontology, vol. 72, no. 7, pp. 921-931, 2001.

[52] R. Lever and C. P. Page, "Non-anticoagulant effects of heparin: an overview," in Heparin-A Century of Progress, vol. 207 of Handbook of Experimental Pharmacology, pp. 281-305, 2012. 
[53] C. Wada, M. Kataoka, H. Seto et al., "High-turnover osteoporosis is induced by cyclosporin A in rats," Journal of Bone and Mineral Metabolism, vol. 24, no. 3, pp. 199-205, 2006.

[54] L. J. Walsh, "Mast cells and oral inflammation," Critical Reviews in Oral Biology and Medicine, vol. 14, no. 3, pp. 188-198, 2003.

[55] S. Steinsvoll, K. Helgeland, and K. Schenck, "Mast cells-a role in periodontal diseases?" Journal of Clinical Periodontology, vol. 31, no. 6, pp. 413-419, 2004.

[56] P. C. Trackman and A. Kantarci, "Connective tissue metabolism and gingival overgrowth," Critical Reviews in Oral Biology and Medicine, vol. 15, no. 3, pp. 165-175, 2004.

[57] V. J. Uitto, C. M. Overall, and C. McCulloch, "Proteolytic host cell enzymes in gingival crevice fluid," Periodontology 2000, vol. 31, pp. 77-104, 2003.

[58] T. Subramani, L. Dhanaraj, K. Senthilkumar, S. Periasamy, G. Abraham, and S. Rao, "Expression of TNF- $\alpha$ and RANTES in drug-induced human gingival overgrowth," Indian Journal of Pharmacology, vol. 42, no. 3, pp. 174-177, 2010.

[59] G. Atilla and N. Kütükçüler, "Crevicular fluid interleukin1beta, tumor necrosis factor-alpha, and interleukin-6 levels in renal transplant patients receiving cyclosporine A," Journal of Periodontology, vol. 69, no. 7, pp. 784-790, 1998.

[60] N. Ohuchi, K. Koike, M. Sano et al., "Proliferative effects of angiotensin II and endothelin-1 on guinea pig gingival fibroblast cells in culture," Comparative Biochemistry and Physiology C, vol. 132, no. 4, pp. 451-460, 2002.

[61] E. R. Levin, “Endothelins," New England Journal of Medicine, vol. 333, no. 6, pp. 356-363, 1995.

[62] D. Fujioka, S. Nakamura, H. Yoshino et al., "Expression of endothelins and their receptors in cells from human periodontal tissues," Journal of Periodontal Research, vol. 38, no. 3, pp. 269-275, 2003.

[63] E. Yamamoto, S. Awano, T. Koseki, T. Ansai, and T. Takehara, "Expression of endothelin-1 in gingival epithelial cells," Journal of Periodontal Research, vol. 38, no. 4, pp. 417-421, 2003.

[64] R. M. Kedzierski and M. Yanagisawa, "Endothelin system: the double-edged sword in health and disease," Annual Review of Pharmacology and Toxicology, vol. 41, pp. 851-876, 2001.

[65] S. Tamilselvan, S. N. Raju, D. Loganathan, S. Kamatchiammal, G. Abraham, and R. Suresh, "Endothelin-1 and its receptors ET(A) and ET(B) in drug-induced gingival overgrowth," Journal of Periodontology, vol. 78, no. 2, pp. 290-295, 2007.

[66] N. Ohuchi, K. Hayashi, K. Iwamoto et al., "Thrombinstimulated proliferation is mediated by endothelin-1 in cultured rat gingival fibroblasts," Fundamental and Clinical Pharmacology, vol. 24, no. 4, pp. 501-508, 2010.

[67] B. H. L. Chua, C. C. Chua, C. A. Diglio, and B. B. Siu, "Regulation of endothelin-1 mRNA by angiotensin II in rat heart endothelial cells," Biochimica et Biophysica Acta, vol. 1178, no. 2, pp. 201-206, 1993.

[68] M. Kohno, T. Horio, M. Ikeda et al., "Angiotensin II stimulates endothelin-1 secretion in cultured rat mesangial cells," Kidney International, vol. 42, no. 4, pp. 860-866, 1992.

[69] G. L. Bakris and R. N. Re, "Endothelin modulates angiotensin II-induced mitogenesis of human mesangial cells," American Journal of Physiology, vol. 264, no. 6, pp. F937-F942, 1993.

[70] H. Kawaguchi, H. Sawa, and H. Yasuda, "Endothelin stimulates angiotensin I to angiotensin II conversion in cultured pulmonary artery endothelial cells," Journal of Molecular and Cellular Cardiology, vol. 22, no. 8, pp. 839-842, 1990.
[71] Y. Takeda, "Phagocytosis of mast cell granules by fibroblasts of the human gingiva," Virchows Archiv A, vol. 406, no. 2, pp. 197-201, 1985.

[72] Y. Asahara, F. Nishimura, H. Yamada et al., "Mast cells are not involved in the development of cyclosporin A-induced gingival hyperplsia: a study with mast cell-deficient mice," Journal of Periodontology, vol. 71, no. 7, pp. 1117-1120, 2000.

[73] R. Reikki, I. T. Harvima, A. Jukkola, J. Ristile, and A. Oikarinen, "The production of collagen and the activity of mast-cell chymase increase in human skin after irradiation therapy," Experimental Dermatology, vol. 13, no. 6, pp. 364-371, 2004.

[74] T. Matsumoto, A. Wada, T. Tsutamoto, M. Ohnishi, T. Isono, and M. Kinoshita, "Chymase inhibition prevents cardiac fibrosis and improves diastolic dysfunction in the progression of heart failure," Circulation, vol. 107, no. 20, pp. 2555-2558, 2003. 


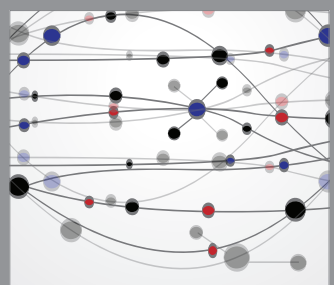

The Scientific World Journal
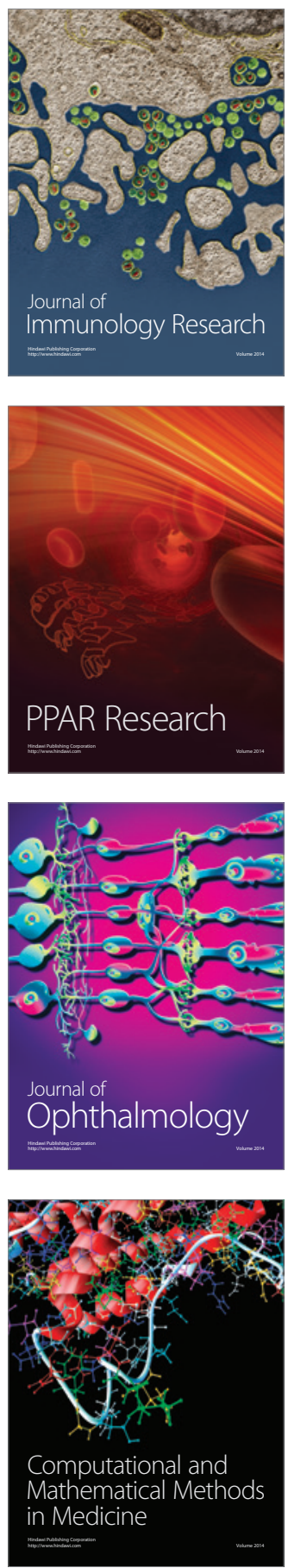

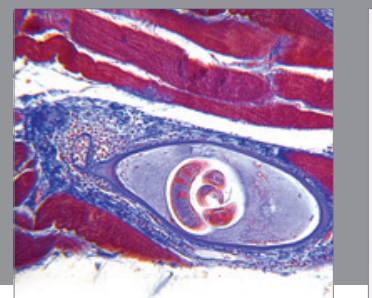

Gastroenterology

Research and Practice
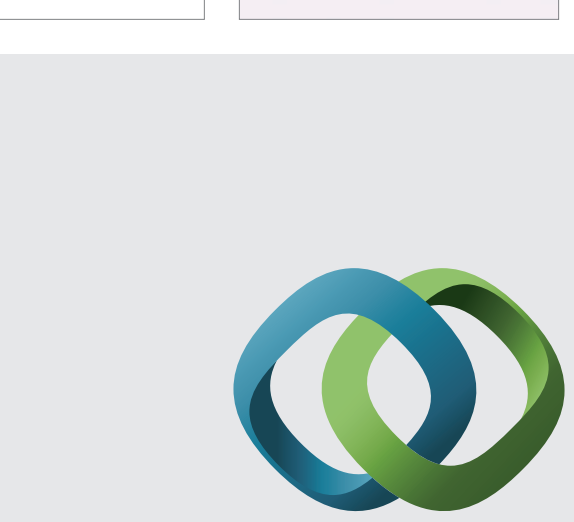

\section{Hindawi}

Submit your manuscripts at

http://www.hindawi.com
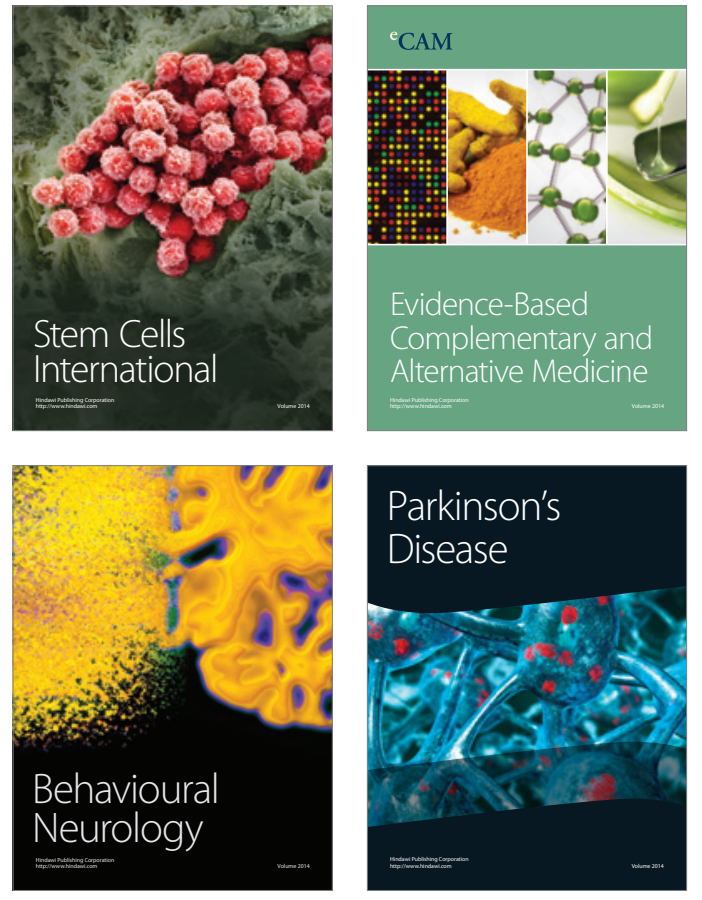
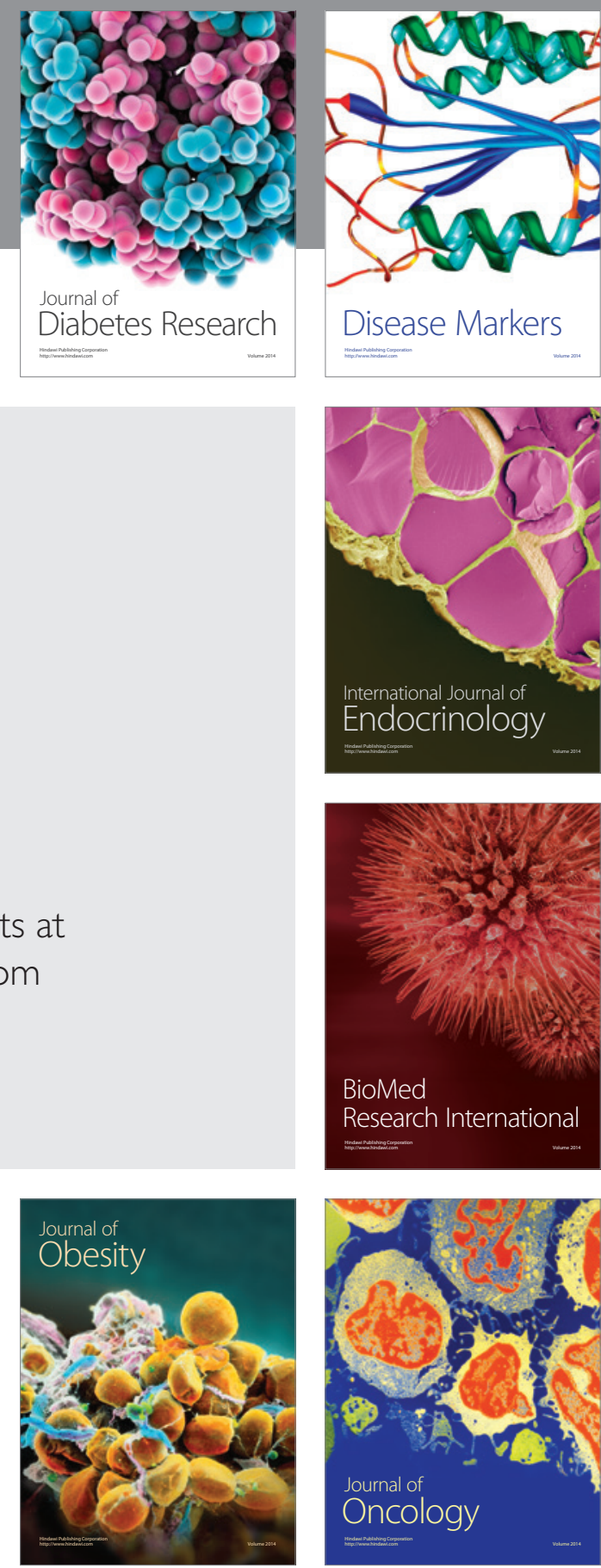

Disease Markers
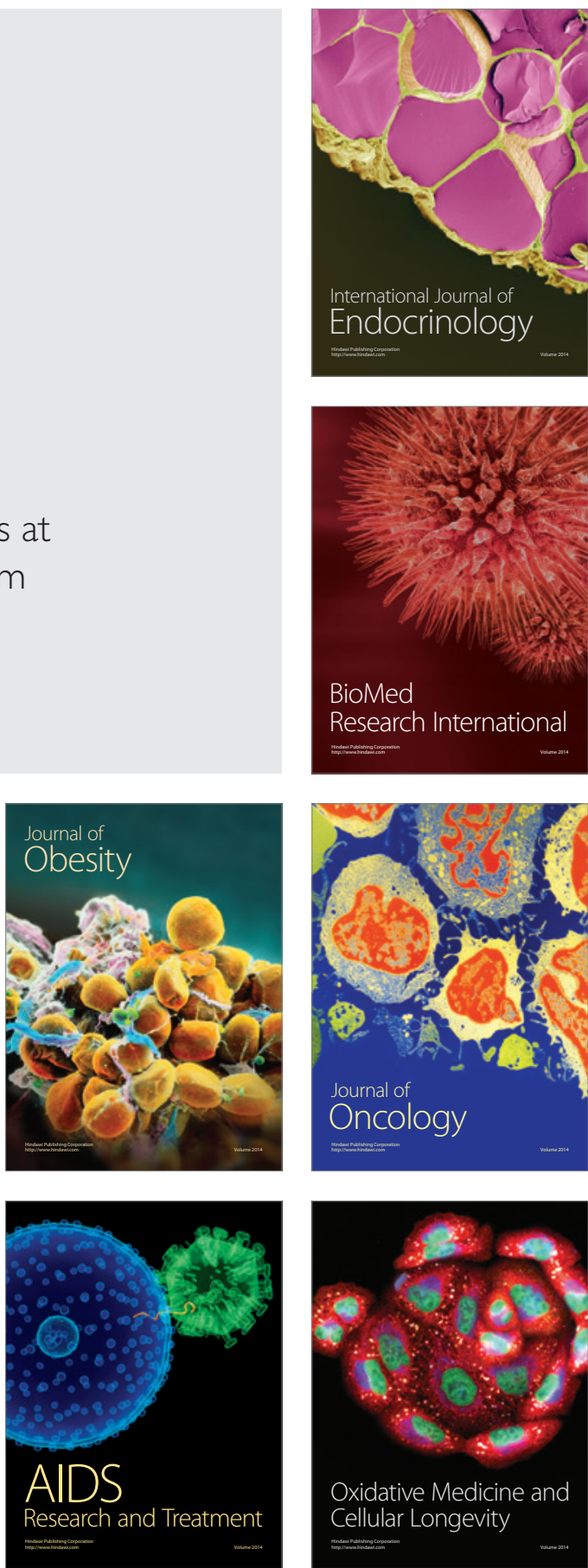